\title{
The Rwandan agrarian and land sector modernisation: confronting macro performance with lived experiences on the ground
}

An Ansoms, Giuseppe Cioffo, Neil Dawson, Sam Desiere, Chris Huggins, Margot Leegwater, Jude Murison, Aymar Nyenyezi Bisoka, Johanna Treidl \& Julie Van Damme

To cite this article: An Ansoms, Giuseppe Cioffo, Neil Dawson, Sam Desiere, Chris Huggins, Margot Leegwater, Jude Murison, Aymar Nyenyezi Bisoka, Johanna Treidl \& Julie Van Damme (2018): The Rwandan agrarian and land sector modernisation: confronting macro performance with lived experiences on the ground, Review of African Political Economy, DOI: 10.1080/03056244.2018.1497590

To link to this article: https://doi.org/10.1080/03056244.2018.1497590

曲 Published online: 30 Jul 2018.

Submit your article to this journal $₫$

Џ Article views: 211

View Crossmark data $\subset$ 


\title{
The Rwandan agrarian and land sector modernisation: confronting macro performance with lived experiences on the ground
}

\author{
An Ansoms ${ }^{a}$, Giuseppe Cioffo ${ }^{\mathrm{a}, \mathrm{b}}$, Neil Dawson ${ }^{c}$, Sam Desiere ${ }^{\mathrm{d}}$, Chris Huggins ${ }^{\mathrm{e}}$, \\ Margot Leegwater ${ }^{\mathrm{a}, \mathrm{f}}$, Jude Murison ${ }^{\mathrm{g}}$, Aymar Nyenyezi Bisoka ${ }^{\mathrm{a}, \mathrm{h}}$, Johanna Treidl' and \\ Julie Van Damme
}

${ }^{a}$ Centre for Development Studies, Université catholique de Louvain, Louvain-la-Neuve, Belgium; ${ }^{b}$ European

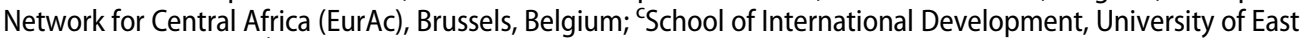
Anglia, Norwich, UK; ${ }^{d}$ Department of Agricultural Economics, Ghent University, Ghent, Belgium; ${ }^{\text {SSchool of }}$ International Development and Global Studies, University of Ottawa, Ottawa, Canada; ${ }^{\mathrm{f}}$ African Studies Centre Leiden, Universiteit Leiden, Leiden, Netherlands; ${ }^{9}$ Institute of Health and Society, Newcastle University,

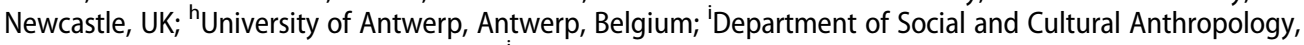
University of Cologne, Cologne, Germany; ${ }^{j}$ Earth and Life Institute, Université catholique de Louvain, Louvainla-Neuve, Belgium

\begin{abstract}
Rwanda has embarked on an ambitious policy package to modernise and professionalise the agrarian and land sector. Its reform fits into a broader call - supported by major international donors - to implement a Green Revolution in Sub-Saharan Africa. After 10 years of implementation, there is increased production output and value-addition in commercialised commodity chains. These are promising results. However, poverty reduction, particularly in more recent years, seems limited. Moreover, microlevel evidence from the field calls into question the long-term sustainability of the agricultural and land sector reform. In this article, a group of researchers, having engaged in in-depth qualitative research in a variety of settings and over an extended period, bring together their main research results and combine their key findings to challenge the dominant discourse on Rwanda as a model for development.
\end{abstract}

\section{La modernisation agricole et foncière au Rwanda : confronter les résultats macro-économiques aux réalités vécues sur le terrain}

\section{RÉSUMÉ}

Le Rwanda a entamé une vaste réforme politique visant à moderniser et à professionnaliser les secteurs agricole et foncier. Soutenu par des bailleurs internationaux, ces réformes s'inscrivent dans une volonté plus large d'introduire une Révolution Verte en Afrique subsaharienne. Après une décennie de mise en œuvre au Rwanda, on observe des résultats prometteurs tels que la croissance de la production agricole et la création de valeur ajoutée dans les filières agricoles commerciales. Néanmoins, la réduction de la pauvreté au

\section{KEYWORDS}

Rwanda; Green Revolution; land reform; agricultural modernisation; statistics; developmental state

\section{MOTS-CLÉS}

Rwanda ; révolution verte ; agriculture ; réforme foncière ; modernisation ; statistiques ; État développementaliste 
cours de ces dernières années semble très limitée. De plus, des observations relevées au niveau micro, en milieux ruraux, questionnent la durabilité de ces réformes. Cet article regroupe les résultats d'un groupe de chercheurs qui ont travaillé sur le Rwanda avec une approche qualitative approfondie dans divers contextes et sur une longue période. Leurs conclusions majeures questionnent le discours dominant présenté par le Rwanda comme un modèle de développement pour le continent africain.

\section{Introduction}

In recent years, states and donors have prioritised agricultural intensification - framed within a plea for a new Green Revolution - as a strategy for growth and development in sub-Saharan Africa (SSA) (Jayne and Rashid 2013; Sanchez, Denning, and Nziguheba 2009). The theory behind such policies posits that formalisation of land tenure, investment in modern inputs, and commercialisation will drive increased production of selected marketable crops, which will be profitable for smallholders if they are integrated into commercial commodity chains. This, in turn, is expected to lead to increased national food security, exports and growth on a national scale (Knickel et al. 2009). This is crucial because in the face of population growth, there is limited availability of new land to support agricultural expansion. Advocates of this new Green Revolution argue that without modern inputs, soil fertility and food production are likely to decline (Breisinger et al. 2011; Denning et al. 2009).

There are, however, a number of economic and structural constraints that stand in the way of a Green Revolution in SSA. These include inequality in landholdings, gendered patterns of access to inputs and other resources, limited public infrastructure in rural areas, and the domination of most economic sectors by politically connected elites (Nyenyezi Bisoka 2014). Such constraints make the impact of contemporary Green Revolution policies on the lives of the tens of millions of rural smallholders in SSA unclear (Dorward et al. 2004). Furthermore, changes in tenure and farming practice can have far-reaching consequences for smallholders (Dawson, Martin, and Sikor 2016). Studies from several countries in SSA have revealed considerable negative impacts of the Green Revolution policy package for significant sections of the rural population, even where agricultural policies have been generally deemed successful (Bezner Kerr 2013; Harrigan 2003; Abro, Alemu, and Hanjra 2014; Kijima, Otsuka, and Sserunkuuma 2011; Wanjala and Muradian 2013). While indicators of agricultural commodity production, export values, and the contribution of agriculture to national economic growth may reveal positive macro-economic impacts, in-depth studies are required to understand the pathways of change for the diverse populations affected.

Rwanda is a very pertinent example to explore this debate. Some authors categorise Rwanda as a development state (Harrison 2016), while others see it as an example of a developmental patrimonial state, in which 'the ruling elite acquires an interest in, and a capability for, managing economic rents in a centralised way with a view to enhancing their own and others' incomes in the long run rather than maximising them in the short run' (Booth and Golooba-Mutebi 2012, 381). The country has been hailed as a 'developmental miracle' (see Mann and Berry 2016 for a discussion on this debate), particularly due to high levels of economic growth (Matfess 2015). 
At the same time, Rwanda's current economic base remains subsistence farming. More than $70 \%$ of the population cultivate for the food they eat. Rwanda has the highest population density on mainland Africa, high population growth rates, small average land holdings at around 0.75 hectares per household and a high incidence of landlessness (McMillan and Heady 2014; NISR 2010). The Rwandan government's ambitious policy programme to intensify and commercialise agriculture was aimed at turning Rwanda from subsistence farming into a modern and developed country. It includes the formalisation of land tenure, the promotion of intensified production of specified marketable crops through use of modern inputs, and regional specialisation where regions concentrate on specific crop combinations depending upon the agro-climate in that region (Republic of Rwanda 2004; MINAGRI 2011). Since the introduction of policies to reshape the agrarian sector, Rwanda has - on the one hand - enjoyed a period of consistently high economic growth (over $5 \%$ per annum since 2008) and a fall in income-based poverty (NISR 2012; UNDP 2007; IMF 2011). On the other hand, citizens' satisfaction with agrarian and land policies has decreased strongly, even according to official data of the Rwandan Government. Between 2013 and 2016, satisfaction with the quantity, quality and performances within the agrarian sector decreased from $57 \%$ to $48 \%$ and from $76 \%$ to $67 \%$ within the land sector (RGB 2014; RGB 2017).

Moreover, these macro-level, aggregate performance indicators only give a broad understanding of Rwanda's performance and do not necessarily reflect people's lived experiences. Several in-depth qualitative studies have revealed the neglected negative impacts of rural policies on smallholders and local populations and the diverse ways in which local households attempt to adapt (Ansoms et al. 2017; Ansoms and Cioffo 2016; Nyenyezi Bisoka 2016; Ansoms and Murison 2013; Cioffo 2014; Van Damme 2013; Huggins 2014a, 2017a, 2017b; Dawson 2015; Leegwater 2015; Treidl 2018). ${ }^{1}$ In this paper, this group of researchers - who engaged in in-depth qualitative research in a variety of Rwandan settings and over an extended period of time - combine their key findings to challenge the dominant discourse on Rwanda as a model for development.

We first comment on the strategic use of statistics by the Rwandan government to legitimise the successfulness of its Green Revolution-based agrarian development. We then highlight the importance of qualitative in-depth research to gain a better understanding of the impact of policies. We focus upon three key policy dimensions: land registration, the Crop Intensification Programme (CIP), and the promotion of cooperatives. Our findings suggest how these policies lead to increased land-tenure and food insecurity, tensions and the exclusion of vulnerable groups. We also dig into the role of key actors in the implementation of agrarian modernisation. The findings show that there is limited space for policy transgression and advocacy by civil society organisations because of the strong top-down character of Rwanda's governance system. In our conclusion, we question the accuracy and dominance of quantitative indicators, and plead in favour of a more nuanced, in-depth and multi-faceted research approach in order to understand the distance between centrally planned policies and local real life.

\section{The power of statistics in the context of Rwanda}

Although statistics are often presented as an unbiased representation of reality, several authors have highlighted how the generation of statistics is part of a complex process (Jerven 2013; Jerven and Johnston 2015; Sandefur and Glassman 2015). In practice, the 
data not only 'describe realities, but they also shape them, since they are used to design or support policies' (Desiere, Staelens, and D'Haese 2016, 1). In Rwanda, statistics are viewed as a major instrument in policy design, implementation and evaluation (Ansoms et al. 2017). Consequently, an important discussion revolves around the extent to which statistics sufficiently capture the impact and successfulness of Rwandan agricultural policies.

The Rwandan 'success story' emphasises the importance of 'a clearly articulated developmental vision' (Biedermann 2015, 15) on the basis of quantitative measures. Within the administrative structures, the 'specific targets and auditing procedures' represented by imihigo performance contracts are characteristic of the Rwandan governance model (Harrison 2016, 361). ${ }^{2}$ Indeed, performance-oriented strategies are embedded throughout the entire administrative system, and fuel the government's record of learning-by-doing (Booth and Golooba-Mutebi 2012) and 'trying new solutions' (Biedermann 2015, 9) based on 'neutral scientific evidence'. However, those characterising Rwanda as engaged in responsive policy-making, or 'problem-driven iterative adaptation' (for example Booth 2015), do not consider how this learning process is marked by a strong topdown governance system. 'The National Dialogue in which implementation targets are reviewed in public' (Booth and Golooba-Mutebi 2014, S192) relies on the imihigo system, which has been critiqued on the basis of its 'top-down' or coercive character and hence cannot be said to reflect local development priorities (Bugingo and Interayamahanga 2010). Many poor citizens are 'too frightened to voice their experiences to those in power' (Mann and Berry 2016, 137). Evidence which contradicts the government narrative is 'contained' or 'managed' at different levels of the government machinery, partly because it is inserted into a hierarchy of knowledge (including 'scepticism about local skills and practices' and assumptions that experts know best (Hasselskog 2015, 158) and partly because the ongoing programming of government activities relies on 'rough classifications and fairly general knowledge' (Hasselskog 2015, 163), intended to result in 'standardised solutions' (Hasselskog 2015, 157) rather than diversified and adapted solutions based on local-level data.

The extensive use of quantitative targets within Rwanda's plans and policies should also be seen within the context of broader global patterns of rendering development activities 'calculable' (Hoey 2015; Kelley and Simmons 2015). ${ }^{3}$ Detailed plans and targets are therefore not only used to guide policy, but also to demonstrate success and to consolidate donor support for the government (for examples, see Ansoms and Rostagno 2012; Ansoms et al. 2017; Burnet 2011, 311; Debusscher and Ansoms 2013, 1124). The ability of the government to maintain its policy-making 'autonomy' is largely based on its ability to deliver developmental improvements, and hence there is considerable incentive for the government to emphasise successes.

Let us first consider Rwanda's agricultural statistics. Desiere, Staelens and D'Haese (2016) have compared various data sources on agrarian outputs: yearly UN Food and Agriculture Organization (FAO) estimates, household surveys, and an agricultural survey. Table 1 illustrates how the different datasets may be interpreted in very different ways with regards to the increase in yields over the period of the implementation of the agricultural reforms (between 10 and 60\% increase). Beyond the point that yields are not the only indicator with which to evaluate the performances of farming systems, Desiere and his co-authors conclude that it is not possible to make strong statements about the success or failure of the reforms in increasing yields. The problem is not a 
Table 1. Overall yields (kg/ha) in Rwanda estimated with different data sources.

\begin{tabular}{llcc}
\hline & \multicolumn{3}{c}{ Yields (kg/ha) } \\
\cline { 2 - 4 } Year & FAO & Household surveys & Agricultural survey* \\
\hline 2006 & 1306 & 1140 & \\
2011 & 2029 & 1370 & 1478 \\
2013 & 2077 & & 1478 \\
\hline
\end{tabular}

*Only season B (March to end of July).

Source: Desiere, Staelens and D'Haese 2016.

lack of data availability - the [Government of Rwanda] undertook significant and laudable efforts to make their datasets publicly available - but rather that different data sources contradict each other and there is no way of telling which dataset is more reliable' (Desiere, Staelens, and D'Haese 2016, 10). The same authors also highlight how in official discourses, both the Rwandan government as well as international donors systematically refer to the most optimistic data material (FAO statistics) whereas these data are the least reliable. They conclude that 'statistics may thus partially have created their own "reality"' (Desiere, Staelens, and D'Haese 2016, 10).

A second major debate revolves around the Rwandan poverty statistics. Rwanda has a good track record in the generation of reliable poverty data. Since 2000/1, several Household Living Conditions Surveys (EICV by their French acronym) have been conducted, providing input to the Economic Development and Poverty Reduction Strategies. Whereas poverty reduction was limited over the 2000/01-2005/16 period, the results of EICV3 indicated an impressive poverty decrease for the 2005/06-2010/11 period (NISR 2015a) (see Table 2). Ansoms et al. $(2017,51)$ reflect on how these results 'were welcomed as the much-needed scientific proof of a successful developmental path and a political justification to allocate aid while less attention was paid to criticism of Rwanda's limited space for political freedom'. They point out that methodological issues related to sampling techniques, to the seasonal fluctuation in agricultural outputs, and to the pressure upon farmers to make statements that reflect government policy may well

Table 2. Growth-poverty-inequality statistics compared.

\begin{tabular}{lcccccc}
\hline & $\begin{array}{c}\text { EICV1 2000/1 } \\
(1)\end{array}$ & $\begin{array}{c}\text { EICV2 2005/6 } \\
(2)\end{array}$ & $\begin{array}{c}\text { EICV3 2010/11 } \\
(2)\end{array}$ & $\begin{array}{c}\text { EICV4 2013/14 } \\
(3) \\
\text { Official } \\
\text { estimates }\end{array}$ & $\begin{array}{c}\text { EICV4 2013/14 } \\
\text { Inflation at } \\
16.7 \%\end{array}$ & $\begin{array}{c}\text { EICV4 2013/14 } \\
\text { Inflation } \\
\text { at } 30 \%\end{array}$ \\
\hline Poor (\%) & 58.9 & 56.7 & 44.9 & 39.1 & 37.4 & 46.1 \\
Extremely poor (\%) & 40.0 & 35.8 & 24.1 & 16.3 & 16.9 & 23.2 \\
Gini & 0.507 & 0.522 & 0.490 & 0.448 & & \\
\hline
\end{tabular}

Notes:

(1) The percentage of poor is based on a poverty line of RWF64,000 (2001 prices). Extreme poverty is calculated on the basis of a poverty line of RWF45,000 (2001 prices) (NISR 2012).

(2) For EICV2 and EICV3, 'poverty was estimated using the poverty line derived from EICV1 after deflating the consumption expenditure in both surveys' (NISR 2015a).

(3) The methodology for calculating the 2013/14 poverty line differs profoundly from the method used for EICV1, 2 and 3, given the reconfiguration of the entire food basket (NISR 2015a). As a result of the changed methodology, the poverty percentage cannot legitimately be compared to past poverty rates.

(4) Poverty rates obtained by assuming that poverty is correctly estimated in EICV3 and inflating the corresponding (food) poverty line by $16.7 \%$, i.e. the inflation rate reported by the NISR from January 2011-January 2014 (Desiere 2017).

(5) Poverty rates obtained by assuming that poverty is correctly estimated in EICV3 and inflating the corresponding (food) poverty line with 30\% (Desiere 2017). 
have influenced the poverty statistics (Ansoms et al. 2017). Particularly, the fact that 2010/ 11 was a good agricultural season whereas 2005/06 was not, deserved more attention in the interpretation of the 'success story' (McKay and Verpoorten 2016). Ansoms et al. (2017) also point to the risk of the statistical success story of Rwanda 'turn[ing] a blind eye to life experiences regarding public policies'.

The release of the 2013/14 EICV4 continued along the same lines with an apparent poverty reduction figure of almost six percentage points (from $44.9 \%$ in $2010 / 11$ to $39.1 \%$ in 2013/14 - see Table 2) (NISR 2015a). However, there was controversy on the methodology used for recalculating the $2013 / 14$ poverty line - and thus, on the comparability of the data between EICV3 (2010/11) and EICV4 (2013/14). The subsequent debate revealed the necessity of a new analysis using the same poverty criteria in both periods. For this purpose, the 2016 NISR 'Poverty Trend Analysis Report 2010/11-2013/14' used two different methodologies and concluded that - regardless of the methodology used poverty decreased by between 6.9 and 7.8 percentage points. However, as the results were sensitive to the inflation rate used to deflate the poverty line between both periods, the debate continued around the validity of the inflation rate of $16.7 \%$ - as reported by the National Institute of Statistics for the 2010/11-2013/14 period (NISR 2016).

Desiere has cross-referenced the price information included in the EICV surveys with the ESOKO surveys and confirms that trends in poverty rates are highly dependent upon the inflation rate. When applying an inflation rate of $16.7 \%$ (as done in the official Rwandan government's analysis), his calculations indicate a poverty decrease of 7.5 percentage points for the 2010/11-2013/14 period - results that are in line with the 2016 NISR report. However, with a more realistic inflation rate of $30 \%$, poverty increased by 1.2 percentage points (Desiere 2017). Anonymous authors (2017) engaged in a similar analysis but based the applicable inflation rate on a Laspeyres price index differentiated by consumption quarter and province calculated on the basis of EICV price data. They come to a poverty increase of between 5\% and 7\% for the 2010/11-2013/14 period, dependent upon the consumption basket used (Anonymous 2017). Also the World Development Indicators ${ }^{4}$ indicate a poverty increase from $60.25 \%$ households below the international poverty line of US $\$ 1.90$ (purchasing power parity) in 2010 , to $60.43 \%$ in 2013.

On the basis of these analyses of statistical data, we may conclude that (1) yields probably increased over the period of the implementation of the agricultural reforms, but less than what the most optimistic but least reliable data source (FAO statistics) suggests; (2) poverty decreased significantly over the 2005/06-2010/11 period but with seasonal effects playing a partial role; (3) inflation over the 2010/11-2013/14 period was probably much higher (around 30\%) than the assumed 16.7\%; and (4) under this assumption, poverty did not decrease significantly over that period, but rather increased.

\section{Digging deeper: the importance of qualitative in-depth research}

Both Rwandan and international policy circles have a preference for quantitative evidencebased input, preferably based on conclusions drawn from nationally representative datasets. However, the generation of large-scale datasets is subject to very strict government control, with researchers being obliged to follow stringent procedures in order to obtain the formal permission to engage in research generating nationally representative data. 
There are severe punishments for researchers not respecting these procedures (NISR 2015b). This complicates the generation of statistical knowledge independent from government influence.

Formal procedures for research approval are less strict for researchers engaging in qualitative in-depth research. However, the value of such research is often considered to be of lesser relevance to policy-making. When contesting the broader picture of the success story, in-depth research is regularly downgraded as the story of one or a couple of hills. ${ }^{5}$ And indeed, the purpose of qualitative research is not to sketch out a representative picture for the entire Rwandan territory, but to understand the ways in which processes work, how different actors relate to each other, and how they develop implicit and explicit discourses and strategies. Each of the authors in this paper (except for Desiere) has done indepth research on the impact of Rwanda's rural modernisation policies. This is set out by author and district in Table 3, and a map of Rwanda at Figure 1 shows these districts.

The exact methodologies, focus and timings of these studies were different. In general, all authors, except for Desiere who concentrated on the statistics, used qualitative methods (semi-structured focus groups and/or individual interviews, participant observation), while Cioffo, Dawson and Van Damme also collected quantitative data on several agricultural aspects. Each study focused largely on the perspective of rural Rwandans themselves and applied considerable attention to gaining the trust of participants to ensure data reliability. This involved emphasising the lack of political affiliation and confidentiality of data. A good claim to the validity of the results is that, despite the lack of incentive among participants to criticise state policy, the consistency of results between the studies in different parts of Rwanda is striking.

Each of the authors wants to emphasise that the raw data are not comparable, nor representative for the whole territory of Rwanda. However, when combined, these studies cover a broad variety of settings and regions, reaching a geographical scale that goes beyond 'a couple of hills', and despite the difference in analytical focus, each of

Table 3. Overview of research settings and topics for each author.

\begin{tabular}{|c|c|c|c|}
\hline Author & Districts of research & $\begin{array}{l}\text { Years of } \\
\text { research }\end{array}$ & Research topics \\
\hline \multirow[t]{2}{*}{ Ansoms } & $\begin{array}{l}\text { Huye/Kamonyi/Muhanga } \\
\text { Nyamagabe/Nyaruguru } \\
\text { Ruhango }\end{array}$ & $\begin{array}{l}2006-07,2011 \\
2013\end{array}$ & $\begin{array}{l}\text { Livelihood strategies and impact of agricultural } \\
\text { policies }\end{array}$ \\
\hline & Rwanda overall & $2015-17$ & $\begin{array}{l}\text { Role of intermediary actors in rural development } \\
\text { policies (with Nyenyezi Bisoka) }\end{array}$ \\
\hline Cioffo & $\begin{array}{l}\text { Huye, Nyamagabe, } \\
\text { Nyamasheke, Nyaraguru, } \\
\text { Musanze }\end{array}$ & $2012-15$ & $\begin{array}{l}\text { Impact of Crop Intensification Programme (CIP) on } \\
\text { local livelihoods and food security }\end{array}$ \\
\hline Dawson & $\begin{array}{l}\text { Nyamasheke/Nyamagabe } \\
\text { Rutsiro }\end{array}$ & $2011-12$ & $\begin{array}{l}\text { (Perceived main drivers of change in) well-being and } \\
\text { priorities of the population }\end{array}$ \\
\hline Huggins & Kirehe/Musanze & $\begin{array}{l}2005-07,2008 \\
2011-13\end{array}$ & $\begin{array}{l}\text { Land rights, agricultural reforms (especially CIP and } \\
\text { cooperatives) }\end{array}$ \\
\hline Leegwater & Ngoma & $2008-10$ & Land-sharing arrangements \\
\hline Murison & $\begin{array}{l}\text { Kamonyi/Muhanga/ } \\
\text { Nyamagabe/ Ruhango/Kirehe }\end{array}$ & 2010,2011 & $\begin{array}{l}\text { Livelihood strategies and impact of agricultural } \\
\text { policies }\end{array}$ \\
\hline $\begin{array}{l}\text { Nyenyezi } \\
\text { Bisoka }\end{array}$ & $\begin{array}{l}\text { Huye/Nyamagabe } \\
\text { Nyamasheke/Nyaruguru/ } \\
\text { Rusizi }\end{array}$ & $2012-17$ & $\begin{array}{l}\text { Role of rural policies in the legitimation of land } \\
\text { grabbing processes and peasant resistance to land } \\
\text { grabbing }\end{array}$ \\
\hline Treidl & Gasabo & 2014-16 & Agricultural everyday life \\
\hline Van Damme & Bugesera/Huye/Kirehe/Rusizi & $2008-12$ & $\begin{array}{l}\text { Innovation in farmer-based cropping systems with a } \\
\text { focus on bananas }\end{array}$ \\
\hline
\end{tabular}




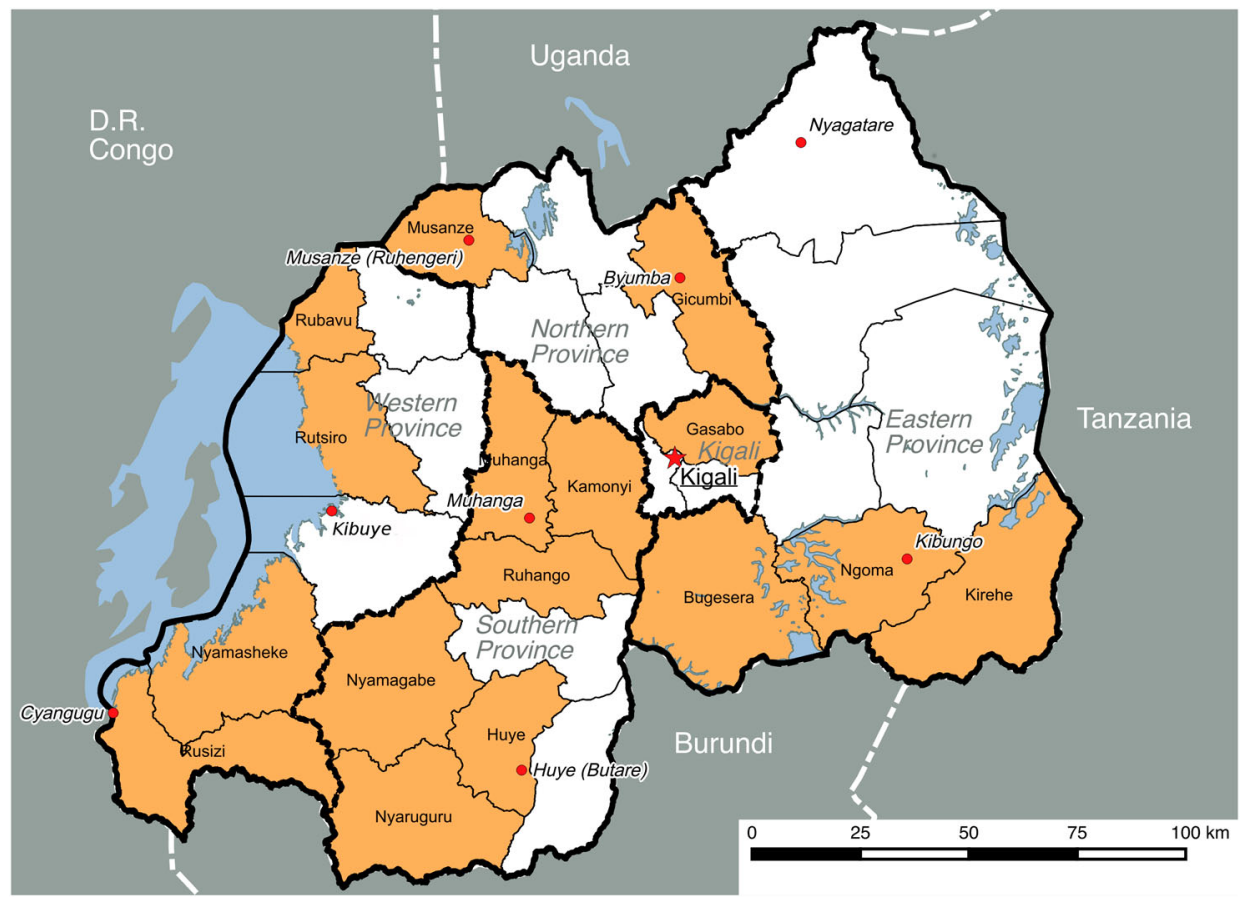

Figure 1. Map of Rwanda showing the districts covered by the authors' research. Source: The authors.

these studies comes to a critical perspective on the impact of recent agrarian and land reforms at the local level, with common themes emerging from these geographically and methodologically diverse qualitative studies.

\section{Rwanda as a model for agricultural modernisation?}

The government has taken a highly interventionist stance in the agricultural sector (as with the economy more generally). The agrarian and land sector modernisation, based originally on the 2005 Organic Land Law, has pushed farmers into obligatory formal land registration. Ensuring secure land rights through a formal land registration system is seen as a crucial step in enhancing investment in the agricultural sector. It also allows the government to have a clear view on and control over land rights (see 'Land registration and land-sharing arrangements' section below). The CIP - implemented from 2007 onwards - aims to transform Rwanda's family farming into a professionalised sector, and is oriented towards the sale of target crops rather than home consumption (see 'The Crop Intensification Policy' section). Cooperatives are key structures in the organisation of this new agrarian model. Not only do they allow for a more coordinated agrarian approach, they are also instruments in a top-down state-controlled governance model (see 'Cooperatives' section).

\section{Land registration and land-sharing arrangements}

The government of Rwanda assumed that by implementing official registration and titling, land-tenure security would be enhanced. Rural farmland owners can obtain a lease of up to 
99 years. The new land administration is based on a reformed cadastre system that facilitates taxation (GoR 2004, 25-30). However, the 99-year lease made many farmers fear that their land rights would not be secure (Huggins 2014a, 2). In addition, most farmers felt that tenure security is not so much about documented property rights (i.e. provision of leases or deeds) but about security from land disputes within families, or with neighbours or state authorities (Musahara and Huggins 2005, 319; Van Hoyweghen 1999, 368). Since the land registration began, several studies have shown that many farmers felt reluctant to participate in the registration process and to inform authorities about the sizes of their plots (Ansoms 2011a; RISD 2012, 2013). In 2013, only 45\% of respondents countrywide had collected their final land certificate because of the titling fees (RWF1000, or about US $\$ 1.20$ per plot), taxation and 'an overall lack of incentive to own a title' (RISD 2013, 10, 15).

In many areas in Rwanda, land registration also led to an increase in land conflicts (Ansoms 2011a), especially in areas where the authorities had previously engaged in land right reshuffling in response to refugee return, as was the case, for example, in Ngoma District in Southeast Rwanda. In Ngoma, a land-sharing arrangement was implemented in 1996-1997. At that time, most refugees, who were returning to Rwanda after having been in exile since 1994, found their homes and fields occupied. The people occupying their land were refugees who had been in exile since the late 1950s/early 1960s, and who had returned to Rwanda in 1994. The later-returning group of refugees, mainly Hutu, were supposed to share their land with the early group of refugees, who were mainly Tutsi, and every family was to obtain one hectare. Land sharing was not supported by legislation or a decree. Nonetheless, most people regarded it as compulsory, even though the population had been consulted and sensitised. Furthermore, it was implemented in a climate of mutual fear and distrust between the two ethnic groups (Leegwater 2015). For years, their frustration simmered over the land they lost. Although the land-sharing arrangement was never openly criticised, family conflicts and resentment regarding land sharing were the main sources of (land) conflict in Ngoma District (Leegwater 2015, 205), and this resentment was known to local authorities (see also Republic of Rwanda 2007). In 2010, this resentment came to the fore with the beginning of land registration in the area, and the collective realisation that registration would anchor the sharing arrangement in a formal land registration system.

In present-day Rwanda, land conflicts are still widespread and often concern parcels that are already officially registered (see also RISD 2013). At the same time, people often do not report the transactions of officially registered land, particularly not in the case of small land plots; which may generate new land conflicts. In addition, farmers are worried about the ways in which a land register allows authorities to 'govern' land rights. An updated register is a very efficient tool for authorities to push farmers into centrally organised modern farming systems; and to exclude those who resist from access to land (Ansoms et al. 2017; Huggins 2014a, 2014b).

\section{The Crop Intensification Policy}

Next to formal land registration, the Crop Intensification Programme is central to the government's agricultural reform (Cioffo, Ansoms and Murison 2016). Heavily influenced by the 'Green Revolution for Africa' model (AGRA 2014) the programme focuses on four 
axes: (1) land use consolidation; (2) sale of fertilisers and improved seeds; (3) provision of proximity extension services; and (4) improvement of post-harvesting handling and storage (Cioffo, Ansoms and Murison 2016).

Customarily, farming households practised intercropping and cultivated several small plots in different parts of the landscape. Intercropping was a risk management strategy (Van Damme, Ansoms, and Baret 2013). Research has shown that in Rwanda, small, intercropped fields are often more productive than large, monocropped areas (Isaacs et al. 2016; Ansoms, Verdoodt, and Van Ranst 2009; Blarel, Hazell, and Place 1992). However, under the land use consolidation approach, farmers cultivating fields adjacent to each other are obliged to choose a single crop, and use a single cultivation regime (incorporating choices of inputs, and schedules for planning, weeding, harvesting, and other activities). ${ }^{6}$ Farmers cultivating under the CIP have to plant crops prioritised by the government: originally six food crops (maize, wheat, cassava, beans, Irish potatoes, and rice), though other crops, such as soya, have since been added to the list. Farmers in tea- and coffee-growing areas are under similar government monitoring and extension systems (Dawson, Martin, and Sikor 2016). Drought-resistant and low-input food security crops, such as sorghum, and the multi-uses banana crop at the base of traditional farming systems (Van Damme, Ansoms, and Baret 2013), are not included. The priority crops are generally imposed at the administrative level of the sector, which has an average size of approximately 64.5 square kilometres. ${ }^{7}$ Given the generally hilly topography (which presents various slopes, micro-climatic niches, soil conditions and hydrological characteristics), and the fact that 'Rwanda is ecologically diverse for its size' (FEWSNET 2011, 4), a sector represents various agro-ecological conditions. Among other things, imposing specific crops, or the type of one crop, at that scale does not adequately account for agroecological diversity (Van Damme, Ansoms, and Baret 2013). Neither does it account for the complexities of household-level food security and various socio-economic preferences around gendered agricultural labour, food and nutrition (Cioffo, Ansoms, and Murison 2016; Treidl field research notes 2015). Crops in the CIP were chosen following a rather short pilot programme (Ansoms 2009) and very limited consultations (Huggins 2014a). The selection of maize as a priority crop for both dryland areas of Kirehe District (Eastern Province) and mountainous areas of Rutsiro District (Western Province), despite the frequent failure of maize crops due to drought, are examples of the associated negative outcomes (Huggins 2017b; Dawson, Martin, and Sikor 2016).

Land use consolidation is, in theory, voluntary, but it has often been imposed on farmers (Cioffo, Ansoms, and Murison 2016; University of Rwanda 2014; ARD 2008). While official criteria for selecting land for consolidation have not been published, fieldwork suggests that highest-potential land is typically selected (Cioffo, Ansoms, and Murison 2016). Government publications link land consolidation with increased agricultural production. Nevertheless, independent field research shows mixed results. While in one study almost $70 \%$ of farmers reported increased yields associated with CIP (and 18.5\% experienced lower yields) (University of Rwanda 2014), other research found a potential link between land consolidation and food insecurity (Cioffo, Ansoms, and Murison 2016), or suggested that it may benefit wealthier households while disadvantaging poorer families (Clay 2017; Dawson, Martin, and Sikor 2016). Dawson, Martin, and Sikor (2016) found, for instance, that some of those smallholders unable to fully adopt the CIP practices continued to grow prohibited crops in hidden ways, or sold their land, as they feared fines, 
crop destruction or ultimately expropriation and reallocation without compensation. This fear was not exaggerated given that in the previous decade $10 \%$ of 165 households in Dawson, Martin and Sikor's 2016 study had experienced expropriation of land without compensation. Those selling land were typically the poorest households lacking disposable income.

The second aspect of the CIP policy concentrates on delivering agricultural inputs to smallholders, notably government-approved seeds and subsidised fertilisers. Fertilisers were initially subsidised at a rate of $50 \%$ by the government, and were available on credit (Chemouni 2014; Ansoms and Murison, field research notes 2011). In Musanze District, Cioffo, Ansoms, and Murison (2016) found that fertilisers were only officially available to farmers cultivating a minimum of one hectare of land, which is above the average land holding in Rwanda. Moreover, they are intended to only be used for the production of crops approved by the CIP. Paying retrospectively for fertiliser proves problematic when crop yields are low, or destroyed through disease (Ansoms and Murison, field research notes 2011). In recent years, the government has reformed the fertiliser distribution system due to corruption among agro-dealers (Afadhali 2016; Ntirenganya 2016) and subsidies are only available to farmers who register for the agricultural extension services (MINALOC/MINAGRI 2016). Under this system, 'farmer promoters' receive financial bonuses based on seed and fertiliser sales in the village (MINALOC/MINAGRI 2016). However, such incentive-based systems have been linked with coercion in fertiliser sales in some cases (Huggins 2014a). While seeds are sometimes provided free of charge when fertiliser is purchased, farmers are often asked to purchase hybrid seeds at commercial prices, which can be very high compared to other varieties. Non-governmental organisations (NGOs) working with the government, such as One Acre Fund, charge high interest rates for inputs provided on credit, making them unaffordable for many (Clay 2017). The situation is particularly problematic for poor households who are obliged to plant priority crops (which require high levels of inputs, especially fertiliser) but are unable to afford those inputs, and hence risk crop failure (Dawson, Martin and Sikor 2016). By restricting crop types, the CIP has limited households' abilities to produce organic manure as an alternative - notably through the reduction of available (beer) banana trees (Cioffo, Ansoms, and Murison 2016; Van Damme, Ansoms and Baret 2013). Seeds and other inputs are not always available at the correct times, impacting yields (Huggins 2014a; Clay 2017). More generally, an insistence on the use of hybrid seeds is eroding local agro-diversity, which has historically been supported by the informal exchange of seed between farmers.

The third key element is agricultural extension, which has 'advisory', 'monitoring' and 'enforcement' functions. Agronomists, in conjunction with local authorities, ensure that fertiliser is used only on government-approved crops, oversee land use consolidation, and often focus on government-approved crops to the exclusion of others (Huggins 2014b). Various punishments have been used against farmers failing to follow the CIP, including fines, destruction of crops, and sometimes even detention (Cioffo, Ansoms, and Murison 2016; Huggins 2014a; Ansoms 2009). Because the activities of agronomists, particularly government staff, but also private and NGO personnel, are generally guided by targets in District Development Plans and local imihigo performance contracts, programme implementers tend to overlook 'local repositories of tacit or vernacular knowledge' (Ansoms 2009, 289) regarding past histories with different crops, soil 
characteristics and the climate, which have important consequences for overall production. More generally, farmers' organisations, which often receive funding for providing training for cooperatives in CIP approaches, have often chosen to keep quiet about farmer's complaints about the CIP. This reduces their credibility and effectiveness as advocacy organisations (Huggins 2017b; see also 'The role of civil society organisations in modern agriculture' section below).

The fourth angle of the CIP policy is post-harvest storage and the sale of crops. This has involved the construction of useful infrastructures and new warrantage schemes (IFDC 2012). Marketing is largely managed through cooperatives. However, local authorities have been involved in facilitating contacts with buyers and negotiating prices. In some cases, cooperative leaders were essentially appointed by local authorities, and cooperative governance may be opaque (Huggins 2014a; Ansoms and Murison 2012; see also 'Cooperatives' section below). Smallholders are often obliged to market all their CIP crops through the cooperatives (and are often unable to reserve some for home consumption), making the process vulnerable to various forms of corruption and elite capture of the proceeds (as described in more detail below). In quite some cases, prices offered by the cooperatives to farmers are below market price (Ansoms et al. 2014).

The CIP can be seen as a process of simplifying agricultural systems (as well as making them more input-oriented). This has frequently proved counter-productive in terms of ensuring long-term sustainability of agro-ecological systems, as the human, climatic and agro-ecological context has in many areas proven to be too complex and variable for the sustained success of such a simple and rigid model.

\section{Cooperatives}

Following the 2006 Policy on the Promotion of Cooperatives (GoR 2006) and the subsequent cooperative law in 2007 (GoR 2007), the Rwandan government launched a revival of the country's cooperative 'movement'. This led to an increase of registered agricultural cooperatives from 645 in 2008, to 2033 in 2015 (Verhofstadt and Maertens 2014, 4; Rwanda Cooperative Agency 2015). Some emerged from local farmer initiatives (Treidl, field research notes 2015), while others were established by local authorities within the framework of imihigo contracts (Huggins 2017b) or encouraged by NGOs, state-led development, or investment programmes. In some cases, policy entrepreneurs took advantage of the new policy to take a lead in the cooperative movement, and to appropriate power over land and people (Huggins 2017b; Nyenyezi Bisoka 2016; Ansoms and Murison 2012).

Voluntary and open membership in a cooperative is listed as a first guiding principle in the cooperative law (GoR 2007, 3). However, farmers often lack attractive alternatives to freely choose whether they really want to participate in a cooperative. If their plots are situated within the area of consolidation, farmers may be compelled to cooperate because they may lose their land rights if they do not opt in (Huggins 2017b, see also Van Damme 2013). This situation is exacerbated in the state-owned marshlands. Since the rights to use to the marshlands are no longer given to individuals, farmers are obliged to group together and form cooperatives. In several cases this has led to the formation of 'fake' cooperatives either with the farmers' primary intent to maintain the use-rights to 'their' formerly cultivated plots (Treidl, field research notes 2016; Ansoms and Murison 2012), 
or to the appropriation of valuable marshlands and labour force by elites for their personal profit.

The opportunity to enter a cooperative depends on a farmer's financial situation (e.g. the ability to pay the cooperative entry fees or membership contributions) (Treidl 2018; Huggins 2013; Ansoms et al. 2014). It was observed that cooperative membership was more feasible for wealthier farmers rather than poor or landless farmers (Dawson, Martin and Sikor 2016; Treidl, field diary 2015). Furthermore, becoming a cooperative member also depends upon a farmer's personal network, level of education, access to information (e.g. about constitutive meetings) and labour capacity (Ansoms et al. 2014; Verhofstadt and Maertens 2014).

Upon becoming a cooperative member, farmers face different constraints during agricultural production (Van Damme 2013). The cooperative's liability for state regulations such as the CIP or the land consolidation, as well as the increased level of 'supervision' by local and state authorities to engage in modern farming, comes with a loss of autonomy (Cioffo, Ansoms, and Murison 2016; Huggins 2014a). Farmers need to adjust their daily routines and responsibilities to the new and often inflexible cropping regime which tends to disregard the heterogeneous living situations of the cooperative members (Treidl 2018). This large-scale production scheme puts a lot of pressure on farmers, especially on poor households with limited financial, labour and time capacity, such as female-headed households (Verhofstadt and Maertens 2014). Furthermore, there are climate-change related pressures affecting cooperatives, particularly those focusing on crops that are not necessarily well adapted to local weather conditions (see e.g. Watkiss 2015 on the tea and coffee sectors, and Huggins 2017b for maize cooperatives in Eastern Province).

One of the government's objectives for the cooperative system was to enable farmers to benefit from the economies of scale effects in collective, more efficient, production schemes (GoR 2006, 1, 22). According to the Ministry of Agriculture, cooperatives play a key role in increasing agricultural output through modernised production and facilitating commercialisation. They have helped farmers to access information and loans (GoR and MINAGRI 2013). However, even if higher yields were obtained, cooperative membership did not always translate into higher profits for all cooperative members. In several cases, the costs of commercial inputs or the repayment of loans counterbalanced the better yields (Treidl, field research notes 2015; Huggins 2017b; Ansoms and Murison 2012). Missing payments and opaque cooperative management practices have also been identified as reasons why farmers have not always benefited from increased production (Huggins 2017b). At the time of harvestings, and with large quantities of the crop being harvested, the market price inevitably drops. To counter this, some cooperative leaders kept the crop stored until the price increased. Subsequently, it took a longer time for members to get their money - a problem exacerbated by the fact that the members were not allowed to take a portion of the harvest home for household consumption (Ansoms and Murison, field research notes 2011; Ansoms and Murison 2012). The expected higher productivity of cooperatives is also questionable in cases where the collaboration between investors or the government and the cooperative has failed. In such cases, valuable farmlands regularly lie idle for several seasons because the rights to use them are not sufficiently clarified (Ansoms 2013; Huggins 2017b; Treidl, field diary 2016). Farmers who are forced to join cooperatives that do not provide economic benefits to members may privately voice considerable frustration against the policy and the local and national 
authorities that enforce it (Huggins 2017b, Ansoms and Murison, field research notes 2011).

To summarise, the Rwandan cooperative movement can refer to a solid law and thoughtful policy. Yet, at the level of implementation, several gaps facilitate the structural exclusion of poorer socio-economic groups and more vulnerable farmers. This will continue as long as the heterogeneous socio-economic background of farmers is not taken into account. Top-down approaches tend to lead to a financial burden, to production schemes, and to opaque management structures which undermine the cooperative's claim for inclusiveness, as outlined in the National Cooperative Policy (GoR 2006).

\section{The role of key actors in the agrarian modernisation policies}

The Rwandan government's Vision 2020 document has defined the key policy objectives for the 2000-2020 period. It includes specific agricultural targets, such as putting $50 \%$ of all agricultural land under 'modernised' agriculture by 2020 and increasing average fertiliser use to $15 \mathrm{~kg} / \mathrm{ha} /$ annum (MINECOFIN 2000). These objectives were subsequently translated into national policies and decentralised development programmes at the district and lower level. An effectively organised and strictly coordinated top-down administrative chain (Ingelaere 2007) renders local authorities responsible for reaching policy objectives (see 'The role of local authorities in modern agriculture' section). Both governmental agencies and civil society organisations (see 'The role of civil society organisations in modern agriculture' section) are pushed into a target-driven approach to help meet objectives laid out in local imihigo contracts.

\section{The role of local authorities in modern agriculture}

The strength and the reach of the Rwandan state under the Rwandan government have been analysed through different lenses, using different sets of state programmes and interventions as proxies for the demonstration of the ability of the state to extend its reach on the 'thousand hills' (Burnet 2008; Nyenyezi Bisoka 2016). For example, in a study of unity and reconciliation policies, Purdeková (2011) showed how the Rwandan state is characterised by a high level of 'presence' and a tightly controlled environment populated by local authorities accountable towards the centre.

The ability to mobilise the country's resources and population for the aim of economic development, is also evident in the Rwandan government's agricultural and land policy documents, as well as in the elaboration of different sorts of policies and their implementation on the ground. The governing of the country's (mostly rural) population serves the aim of transforming Rwanda into a target-driven society from the highest to the lowest level' (Ansoms 2011b, 240). This goal is accomplished through a tightly controlled system of decentralised administration, organised from the top to the bottom in provinces, districts, sectors, cells and, finally, imidugudu. The imihigo performance contracts at each level ensure that the setting of policy targets resides with the political centre, giving rise to a 'de-politicized but technocratic local elite' (Chemouni 2014, 253).

At the same time, however, we see that local authorities can influence the implementation of nationally defined policy objectives. There is elite capture of opportunities provided by the reconfiguration of land and production processes, either by formal 
authorities, or by other influential actors. Ansoms and Murison (2012) have extensively documented how in the initial stages of the marshland land rights reconfiguration, certain elites were capable of claiming land rights through the instrumentalisation of associative and cooperative structures. Huggins (2017b) identifies a similar dynamic in a cooperative in Musanze District, Northern Province; and documents how administrators and cooperative leaders have been involved in black-market sales of subsidised fertiliser, intended for maize production, in Kirehe District, Eastern Province.

However, local authorities also use their margin for manoeuvre to respond to locally formulated claims and complaints about certain policy aspects to adapt policy measures to local conditions. For example, Cioffo (field notes 2014; see also Ansoms and Cioffo 2016) documented that local authorities were increasingly flexible with regards to farmers' demands to produce sorghum next to or instead of the imposed maize crop type. The same goes for beans, as Van Damme observed tolerance from local authorities to allow beans to be planted with banana, as a main source of protein for the rural population in Eastern Province (Van Damme, Ansoms, and Baret 2013, see also Huggins 2017b). Local authorities are indeed often aware of the difficulties producers face when having to adapt to the new agricultural model. There are two main reasons why such discussions seldom reach higher up to the Ministry of Agriculture. First, the imihigo performance contracts linked to the programme push authorities to report favourably on programme activities. Second, local authorities are aware of the importance of positive results for the Rwandan government who considers every concession to previous agricultural practices as an obstacle to the reduction of rural poverty. Therefore, local authorities rarely provide 'bad news' on policy implementation to higher-level authorities (Sommers 2012), and this 'limits the possibilities for error correction and policy learning' (Mann and Berry 2016, 139). As the anthropology of public space in Africa has shown over the past 10 years, there is at times a developmental value to the transgression of formal rules (Olivier de Sardan 2008). In other words, local arrangements that transgress formal rules may provide important information on how to adapt policy interventions both at the global and sectorial level. However, the rigid top-down character of the Rwandan governance system offers very limited space to draw lessons from policy transgression on the ground.

\section{The role of civil society organisations in modern agriculture: 'service delivery' versus 'advocacy'}

The involvement of civil society in the Rwandan agricultural reform is limited to its implementation, and, to a lesser extent, its monitoring. Among the civil society organisations involved in the process, from the bottom to the top, we find cooperatives, agricultural organisations and unions, as well as organisations that provide technical support. Civil society participation in the implementation of agricultural policy unfolds within the framework of decentralisation and local governance, as outlined in the Vision 2020 and the Economic Development and Poverty Reduction Strategy (EDPRS). Such institutional frameworks call for the participation of the local population in the planning, implementation and monitoring of development plans. Participation aims at strengthening the accountability of local authorities towards the population, and at improving the performance of decentralised structures in reaching the objectives set out in the development plan as well as in the yearly plans. State and civil society meet at Joint Action Forum 
(JAF), where development plans are harmonised and priorities, and expected results are integrated into the imihigo performance contracts (Ansoms and Nyenyezi Bisoka, field research notes 2015-2017).

However, three important factors prevent civil society from making a substantial contribution to the elaboration of the national agricultural strategy. First, the Green Revolution orientation of the agricultural strategy was never up for debate with civil society organisations. Rather, it is inserted within a wider strategy adopted by the African Union and the Rwandan Ministry of Agriculture. Second, the structures and organisations that should mediate and facilitate the participation of local society in policy-making - such as the JAF meetings - were put in place only after the policy was adopted (Panait and Nyenyezi Bisoka 2014). Finally, and most importantly, civil society organisations are considered by the government as 'service providers' who are - just like local authorities - to be held accountable on the basis of quantifiable objectives set by the imihigo performance contracts. This calls into question the right of civil society organisations to function independently from the government agenda, and downgrades their legitimacy to function as a watchdog.

Nevertheless, despite the limited space for advocacy, field data from the ground (in-depth interviews, focus groups and participative theatre) show that civil society organisations do successfully advocate for amendments to the often rigid rules of the CIP policy at the local level. For instance, in different locations, as a result of civil society advocacy, local authorities allowed farmers to grow crops other than the ones targeted through the CIP (Huggins 2017b; Van Damme, Ansoms, and Baret 2013, c). Similarly, at times farmers could keep part of the production for household consumption that would normally be destined for the cooperative. Furthermore, there are numerous examples of authorities allowing farmers to choose the fertiliser, the tracing of hedgerows, or the planting of trees in consolidated plots in case of degradation or erosion. Finally, in different districts changes have been made to the pricing mechanisms of crops after civil society organisations exposed how local authorities were abusing their power position to force unfavourable prices on producers (especially in rice and maize value chains) (Nyenyezi Bisoka 2016).

Nevertheless, the capacity of civil society organisations to bear weight on higher-level policy objectives remains limited. Criticism on local 'deficiencies' is tolerated - and in quite some cases even welcomed - but only to the extent that it does not call into question the overall Green Revolution rationale of the agrarian modernisation policy. In a way, the advocacy role of civil society tolerated by the Rwandan government is limited to criticising 'accidental' flaws in the system, but not to draw attention to systemic flaws inherent to the implementation of an agrarian model that clashes with the rationale of the large majority of smallholder farmers.

\section{Conclusion and reflection on reconfiguration of social and political ecologies}

The agricultural and land sector modernisation should be viewed as a neoliberal development project that intends to co-opt farmers into a state-managed system of commercialisation and to render them more dependent on state services as well as private firms and banks providing hybrid seeds, fertilisers, and credit. Through this dependency, the state 
actively enforces and consolidates its power. The words below from a farmer from Southern Rwanda clearly point this out:

We have less and less land, and we need more and more money [ ... ]. We also have many other obligations that enter into the framework of the performance contracts, commitments that we make towards the local authorities. Our agriculture has to produce money to cover all these expenses. [...] At this point, we would like the state to give us a greater margin of freedom in our activities. We know we have to evolve and to set aside traditional agriculture. It [traditional agriculture] is no longer adapted to Rwanda but also to a world that opens up and needs money. [... ] They should leave us more choice to cultivate what we think is profitable. We are after all cultivateurs - commerçants; little agronomic enterprises, as agronomists would say. (Farmer, June 2016)

This article has tried to add a layer of complexity to the assessment of the Rwandan agricultural modernisation effort. This brings us to three important insights that extend beyond the Rwandan case.

First, relying on household-level survey data as the only legitimate source of information on poverty reduction and social development is a risky approach. Empirical evidence derived from both statistical analysis and micro-level qualitative research problematises the overreliance of state-generated national-level statistical analysis. Not only does this information source risk being misleading in case of shaky methodologies, but it is inherently designed to overlook and simplify the complex details of social reality (Dawson 2015). Aggregation of household-level data adds an additional process of simplification. In particular, differentiated impacts of agricultural policies - dependent upon geographical, topographical, and socio-economic varieties - are not readily identified in aggregated statistics. Figures are not sensitive to people's lived experiences, and particularly to those of vulnerable groups (poor people, women, and historically marginalised people). In the case of Rwanda's land and agrarian policies, broad-scale, aggregate evaluation metrics used to claim policy success contrast markedly with local experiences due to their oversight of negative impacts on many, particularly the poorest rural inhabitants, through diminished land-tenure security, disrupted subsistence production, traditional farming methods and associated social practices.

Second, national-level statistics are instrumentalised by governance structures. Through the process of codifying they 'do not merely describe, observe, and map; they strive to shape a people and landscape that will fit their techniques of observation' (Scott 1998, 82). This is what Scott calls a panoptical view: one that is placed at the centre and relies on the (complex) simplification of society as a collection of identifiable and classable units 'with registered, unique names and addresses keyed to grid settlements; who pursue single, identifiable occupations; and all of whose transactions are documented according to the designated formula and in the official language' (82). The creation of statistical information is not only a descriptive activity, but a highly normative one: it narrates reality, and in doing so, it shapes it in conformance with the vision held by the central observer.

Third, this panoptical view is, because of its central and typifying nature, blind to dynamics that do not fit into expected patterns of behaviour, economic activity or interests. In other words: 'there are virtually no other facts for the state than those that are contained in documents standardized for that purpose' (Scott 1998, 84). This risks creating vicious cycles in which the evaluation and reformulation of state policy do not benefit 
from grassroots feedback. Such a top-down approach in Rwandan policy-making means that they rarely reach out to people at a local level. While those in favour of Rwanda's developmental model argue that 'Rwandan policies have been changing in the face of failure and are therefore not the result of a fixed ideological position' (Booth 2015, S186) this ignores the political economy of policy-making. The question of whether households join cooperatives, purchase inputs and plant government-approved crops willingly, or under duress, is crucial to understanding the long-term sustainability of the agricultural reform as well as its impacts on the political climate of the country.

In short, while the agricultural modernisation programme in Rwanda has undoubtedly produced some of the desired results (increased economic growth, increased agricultural production output), the extent to which it has benefited vulnerable population groups - a large majority of the Rwandan population, such as poor smallholders, female-headed households, single mothers and other marginalised groups - must be called into question. National-level aggregated statistics portray only a part of the picture but cannot account for the many cases of local failures, amendments and contestations. To effectively engage citizens and local society in the policy-planning process, a more nuanced and multifaceted approach is needed. This includes independent research, monitoring and evaluation that complement standardised measures of representation with an in-depth, qualitative and realistic assessment of rural Rwandans needs and challenges.

\section{Notes}

1. The authors cited here are the authors of the article.

2. Imihigo performance contracts set specific levels of government objectives to be reached within all levels of the administration. Examples include targets on the amount of maize that a given sector should be growing or the number of households that should sign up for public mutual health insurance. Imihigo are signed yearly, ensuring that 'local authorities are held accountable to their targets' (Biedermann 2015, 15). They are not restricted to government administrative levels, but are also signed at the household level.

3. This attention to national-level statistics, and to the detailed planning of state intervention and social life is not unique or new, but it is one of the defining features of modern states. This is clearly described by anthropologist James Scott who writes that, thanks to the science of statistics for the first time: '[S] ociety became an object that the state might manage and transform with a view toward perfecting it. [ ... ] It was possible to conceive of an artificial, engineered society designed, not by custom and historical accident, but according to conscious, rational, scientific criteria. [...] The working poor were often the first subjects of scientific social planning' (Scott 1998, 96).

4. http://data.worldbank.org/indicator/SI.POV.DDAY?locations=RW\&view=chart.

5. Various authors of this article have had this experience when engaging in policy discussions with both Rwandan and policy-makers and international actors influencing policy-making in Rwanda.

6. There are other models for land consolidation as laid out in MINAGRI (2011) but those described above are the most commonly found in practice.

7. There are 416 sectors in Rwanda, which has a total land area of $26,798 \mathrm{~km}^{2}$.

\section{Disclosure statement}

No potential conflict of interest was reported by the authors. 


\section{Notes on contributors}

An Ansoms (Université catholique de Louvain, Belgium) has a $\mathrm{PhD}$ in Applied Economics, and is a Professor in Development Studies. Her research focuses upon natural resource conflicts and challenges for rural development in the Great Lakes Region of Africa. She is the main coordinator of the Land Rush Project (for more information, see www.land-rush.org).

Giuseppe Cioffo (European Network for Central Africa - EurAc, Belgium) is a Program and Policy Officer. He is interested in the social and environmental dynamics linked to Green Revolution models as well as in small family farming and agrarian change in developing countries. He is preparing to defend his thesis on the processes of agrarian modernisation in Rwanda.

Neil Dawson (University of East Anglia, UK) is a specialist in poverty, well-being and environmental justice research exploring the perspectives of rural people in developing countries, particularly marginalised groups among them. His work, in sub-Saharan Africa, Asia and South America, covers the following interlinked themes: agriculture; sustainable development and poverty alleviation; biodiversity conservation, and climate change mitigation and adaptation.

Sam Desiere (Ghent University, Belgium), is an expert in statistics and has focused on data quality of household surveys in developing countries, including Rwanda and Burundi

Chris Huggins (University of Ottawa, Canada) specialises in natural resources rights in East and Central Africa, particularly the political economy of artisanal mining, land rights, and agricultural reform.

Margot Leegwater (Université catholique de Louvain, Belgium, and African Studies Centre Leiden, Netherlands) has carried out research on land-related policies and how these affect social relations in Rwanda.

Jude Murison (Newcastle University, UK) specialises in the political economy of development in Rwanda and Uganda. Her research focuses on human rights, transitional justice, forced migration, health, rural livelihoods and agricultural production.

Aymar Nyenyezi Bisoka (Université catholique de Louvain, Belgium and University of Antwerp, Belgium) has expertise in land grabbing by local elites, and issues of power and resistance in relation to access to natural resources in the Great Lakes Region of Africa.

Johanna Treidl (University of Cologne, Germany) is a PhD student in the Department of Social and Cultural Anthropology. In her thesis, she investigates Rwandan marshland cooperatives in the context of agrarian change. Her interests focus on gender, household dynamics and food security.

Julie Van Damme (Université catholique de Louvain, Belgium) has studied agricultural innovation with a comparative approach in the Great Lakes Region of Africa, in particular with regard to banana-based cropping systems.

\section{References}

Abro, Z. A., B. A. Alemu, and M. A. Hanjra. 2014. "Policies for Agricultural Productivity Growth and Poverty Reduction in Rural Ethiopia." World Development 59 (July): 461-474.

Afadhali, J. P. 2016. "New Model to get Fertiliser to Rwanda Farmers." The East African, September 24. http://www.theeastafrican.co.ke/Rwanda/News/New-model-to-get-fertiliser-to-Rwandafarmers-/1433218-3393388-1uwcaq/index.html.

AGRA (Alliance for a Green Revolution in Africa). 2014. Planting the Seeds of a Green Revolution in Africa. Nairobi: AGRA

Anonymous. 2017. "Rwanda Poverty Statistics: Exposing the 'Donor Darling." Roape.net, May 31. http://roape.net/2017/05/31/rwandan-poverty-statistics-exposing-donor-darling/.

Ansoms, A. 2009. "Faces of Rural Poverty in Contemporary Rwanda: Linking Livelihood Profiles and Institutional Processes." PhD diss., University of Antwerp. 
Ansoms, A. 2011a. "Views from Below on the Pro-poor Growth Challenge: Agrarian Policies in the Context of Rural Rwanda." In Natural Resources and Local Livelihoods in the Great Lakes Region of Africa: A Political Economy Perspective, edited by A. Ansoms and S. Marysse, 123-145. Basingstoke/ New York: Palgrave Macmillan.

Ansoms, A. 2011b. "Rwanda's Post-Genocide Economic Reconstruction." In Remaking Rwanda. State Building and Human Rights after Mass Violence, edited by S. Straus and L. Waldorf, 240-251. Madison, WI/London: The University of Wisconsin Press.

Ansoms, A., 2013. "Large-scale Land Deals and Local Livelihoods in Rwanda: The Bitter Fruit of a New Agrarian Model." African Studies Review 56 (3): 1-23.

Ansoms, A., G. Cioffo, C. Huggins, and J. Murison. 2014. "The Reorganisation of Rural Space in Rwanda: Habitat Concentration, Land Consolidation, and Collective Marshland Cultivation." In Losing Your Land: Dispossession in the Great Lakes, 163-85, edited by A. Ansoms and T. Hilhorst, 163-185. Woodbridge, UK: James Currey.

Ansoms, A., and G. Cioffo. 2016. "The Exemplary Citizen on the Exemplary Hill: The Production of Political Subjects in Contemporary Rural Rwanda.” Development and Change 47 (6): 1247-1268.

Ansoms, A., E. Marijnen, G. Cioffo, and J. Murison. 2017. "Statistics Versus Livelihoods: Questioning Rwanda's Pathway out of Poverty." Review of African Political Economy 44 (151): 47-65. doi: 10.1080/03056244.2016.1214119.

Ansoms, A., and J. Murison. 2012. “De 'Saoudi' au 'Darfour': L'histoire d'un marais au Rwanda." In L'Afrique des Grands Lacs: Annuaire 2011-2012, edited by F. Reyntjens, S. Marysse, and S. Vandeginste, 375-396. Paris: L'Harmattan.

Ansoms, A., and J. Murison. 2013. "Formalizing the Informal in Rwanda: From Artisanal to Modern Brick and Tile Ovens." In Securing Livelihoods: Informal Economy Practices and Institutions, edited by I. Hillenkamp, F. Lapeyre, and A. Lemaître, 235-253, Oxford: Oxford University Press.

Ansoms, A., and Rostagno. 2012. "Rwanda's Vision 2020 Halfway Through: What the Eye Does Not See." Review of African Political Economy 39 (133): 427-450.

Ansoms, A., A. Verdoodt, and E. Van Ranst. 2009. "The Inverse Relationship between Farm Size and Productivity in Rural Rwanda.” IOB Discussion Paper. Antwerp: Institute of Development Policy and Management.

ARD (Associates for Rural Development). 2008. Land Related Program Activities Completion Report. Washington, DC: USAID.

Bezner Kerr, R. 2013. "Seed Struggles and Food Sovereignty in Northern Malawi." Journal of Peasant Studies 40 (5): 867-897.

Biedermann, Z. 2015. Rwanda: Developmental Success Story in a Unique Setting. Centre for Economic and Regional Studies HAS Institute of World Economics Working Paper 213. http://real.mtak.hu/25192/1/WP_213_Biedermann.pdf.

Blarel, B., P. Hazell, and F. Place. 1992. "The Economics of Farm Fragmentation: Evidence from Ghana and Rwanda." The World Bank Economic Review 2: 233-254. http://documents. worldbank.org/curated/en/263281468771580322/The-economics-of-farm-fragmentationevidence-from-Ghana-and-Rwanda.

Booth, D., 2015. "Towards a Developmental State Concept that is Fit for Purpose (In the 21st Century, in Africa).” Working Paper. London: Overseas Development Institute.

Booth, D., and F. Golooba-Mutebi. 2012. "Developmental Patrimonialism? The Case of Rwanda." African Affairs 111 (444): 379-403.

Booth, D. and F. Golooba-Mutebi. 2014. "Policy for Agriculture and Horticulture in Rwanda: A Different Political Economy?” Development Policy Review 32 (s2): s173-s196.

Breisinger, C., X. Diao, J. Thurlow, and R. M. A. Hassan. 2011. "Potential Impacts of a Green Revolution in Africa: The Case of Ghana." Journal of International Development 23 (1): 82-102.

Bugingo, I., and R. Interayamahanga. 2010. A Study on the Development and Use of Governance Indicators in Rwanda. Kigali: Institute of Research and Dialogue for Peace.

Burnet, J. E. 2008. "Gender Balance and the Meanings of Women in Governance in Post-Genocide Rwanda." African Affairs 107 (428): 361-386. doi:10.1093/afraf/adn024. 
Burnet, J. E. 2011. "Women Have Found Respect: Gender Quotas, Symbolic Representation and Female Empowerment in Rwanda." Politics \& Gender 7 (3): 303-334.

Chemouni, B. 2014. "The Political Economy of the Fertilizer Subsidy Reform in Rwanda and Burundi." In L'Afrique des Grands Lacs: Annuaire, 2013-2014, edited by F. Reyntjens, M. Verpoorten, and S. Vandeginste, 483-506. Paris: L'Harmattan.

Cioffo, G. 2014. "Les Petits Agriculteurs face à la modernisation rurale dans la province du Nord du Rwanda: consolidation de l'usage des terres, distribution d'engrais améliorés et sécurité alimentaire." Afrique des Grands Lacs, Annuaire 2014-2015. Paris: L'Harmattan.

Cioffo, G., A. Ansoms, and J. Murison. 2016. "Modernising Agriculture through a 'New' Green Revolution: The Limits of the Crop Intensification Programme in Rwanda." Review of African Political Economy 43 (148): 277-293.

Clay, N. 2017. "Agro-environmental Transitions in African Mountains: Shifting Socio-spatial Practices Amid State-led Commercialization in Rwanda." Annals of the American Association of Geographers 107 (2): 360-370.

Dawson, N. 2015. "Bringing Context to Poverty in Rural Rwanda: Added Value and Challenges of Mixed Methods Approaches.” In Mixed Methods Research in Poverty and Vulnerability, edited by K. Roelen and L. Camfield, 61-86. Basingstoke/ New York: Palgrave Macmillan.

Dawson, N., A. Martin, and T. Sikor. 2016. "Green Revolution in Sub-Saharan Africa: Implications of Imposed Innovation for the Wellbeing of Rural Smallholders." World Development 78 (February): 204-218.

Debusscher and Ansoms. 2013. "Gender Equality Policies in Rwanda: Public Relations or Real Transformations?” Development \& Change 44 (5): 1111-1134.

Denning, G., P. Kabambe, P. Sanchez, A. Mali, R. Flor, R. Harawa, P. Nkhoma, et al. 2009. "Input Subsidies to Improve Smallholder Maize Productivity in Malawi: Toward an African Green Revolution.” PLoS Biology 7 (1): e23. doi:10.1371/journal.pbio.1000023.

Desiere, S. 2017. "The Evidence Mounts: Poverty, Inflation and Rwanda." ROAPE.net, June 28. http://roape.net/2017/06/28/evidence-mounts-poverty-inflation-rwanda/.

Desiere, S., L. Staelens, and M. D’Haese 2016. “When the Data Source Writes the Conclusion: Evaluating Agricultural Policies.” The Journal of Development Studies 52 (9): 1372-1387.

Dorward, A., J. Kydd, J. Morrison, and I. Urey. 2004. "A Policy Agenda For Pro-poor Agricultural Growth." World Development 32 (1): 73-89.

FEWSNET. 2011. Livelihoods Zoning "Plus" Activity in Rwanda. Nairobi: FEWSNET/USAID.

GoR (Government of Rwanda). 2004. National Land Policy. Kigali: Ministry of Lands, Environment, Forests, Water and Mines.

GoR. 2006. National Policy on Promotion of Cooperatives. Accessed September 10, 2014. http:// www.rca.gov.rw/spip.php?article15.

GoR. 2007. Law $N^{\circ}$ 50/2007 of 18/09/2007 Determining the Establishment, Organization and Functioning of Cooperative Organizations in Rwanda. LAW $N^{\circ}$ 50/2007. Kigali: GoR.

GoR and MINAGRI (Ministry of Agriculture). 2013. Strategic Plan for the Transformation of Agriculture in Rwanda - Phase III (PSTA III). Kigali: GoR.

Harrigan, J. 2003. "U-turns and Full Circles: Two Decades of Agricultural Reform in Malawi 19812000.” World Development 31 (5): 847-863.

Harrison, G. 2016. "Rwanda: An Agrarian Developmental State?” Third World Quarterly. 37 (2): 354-370.

Hasselskog, M. 2015. "Rwandan Developmental 'Social Engineering': What Does It Imply and How Is it Displayed?” Progress in Development Studies 15 (2): 154-169.

Hoey, L. 2015. "'Show Me the Numbers': Examining the Dynamics between Evaluation and Government Performance in Developing Countries.” World Development 70 (June): 1-12.

Huggins, C. 2013. Consolidating Land, Consolidation Control: State-facilitated 'Agricultural Investment' through the 'Green Revolution' in Rwanda. LDPI Working Paper 16. The Land Deal Politics Initiative. The Hague: LDPI.

Huggins, C. 2014a. “'Control Grabbing' and Small-scale Agricultural Intensification: Emerging Patterns of State-facilitated 'Agricultural Investment' in Rwanda." Journal of Peasant Studies 41 (3): 365-384. 
Huggins, C. 2014b. Restrictions on Land Use Rights in Rwanda: Understanding the 'Bundle of Land Rights' in Context. Focus on Land in Africa (FOLA) Brief. http://www.focusonland.com/ countries/curbs-on-land-use-rights-in-rwanda-the-bundle-of-rights-in-context/.

Huggins, C. 2017a. "Discipline, Governmentality and 'Developmental Patrimonialism': Insights from Rwanda's Pyrethrum Sector.” Journal of Agrarian Change 17 (4): 715-732. doi: 10.1111/ joac. 12189.

Huggins, C. 2017b. Agricultural Reform in Rwanda: Authoritarianism, Markets and Zones of Governance. London: Zed Books.

IFDC (International Fertilizer Development Center). 2012. CATALIST: Catalyze Accelerated Agricultural Intensification for Social and Environmental Stability: Project Summary. Muscle Shoals, AL: IFDC.

IMF (International Monetary Fund). 2011. Rwanda: Poverty Reduction Strategy Paper - Progress Report Country Report (Vol. 11/154). Washington, DC: IMF.

Ingelaere, B. 2007. Living the Transition: A Bottom-up Perspective on Rwanda's Political Transition. IOB Discussion Paper 2007.06. Antwerp: Institute of Development Policy and Management.

Isaacs, K. B., S. S. Snapp, K. Chung, and K. B. Waldman. 2016. "Assessing the Value of Diverse Cropping Systems under a New Agricultural Policy Environment in Rwanda.” Food Security 8 (3): 491-506.

Jayne, T. S., and S. Rashid. 2013. "Input Subsidy Programs in Sub-Saharan Africa: A Synthesis of Recent Evidence." Agricultural Economics 44 (6): 547-562.

Jerven, M. 2013. Poor Numbers: How we are Misled by African Development Statistics and What to Do About It. Ithaca, NY: Cornell University Press.

Jerven, M., and D. Johnston. 2015. "Statistical Tragedy in Africa? Evaluating the Data Base for African Economic Development." The Journal of Development Studies 51 (2): 11-115.

Kelley, J. G., and B. A. Simmons. 2015. "Politics by Number: Indicators as Social Pressure in International Relations.” American Journal of Political Science 59 (1): 55-70.

Kijima, Y., K. Otsuka, and D. Sserunkuuma. 2011. "An Inquiry into Constraints on a Green Revolution in Sub-Saharan Africa: The Case of NERICA Rice in Uganda." World Development 39 (1): 77-86.

Knickel, K., G. Brunori, S. Rand, and J. Proost. 2009. “Towards a Better Conceptual Framework for Innovation Processes in Agriculture and Rural Development: From Linear Models to Systemic Approaches." Journal of Agricultural Education and Extension 15 (2): 131-146.

Leegwater, M. 2015. Sharing Scarcity: Land Access and Social Relations in Southeast Rwanda. Leiden: African Studies Centre.

Mann, L., and M. Berry. 2016. "Understanding the Political Motivations that Shape Rwanda's Emergent Developmental State." New Political Economy 21 (1): 119-144.

Matfess, H. 2015. "Rwanda and Ethiopia: Developmental Authoritarianism and the New Politics of African Strong Men.” African Studies Review 58 (2): 181-204.

McKay, A., and M. Verpoorten. 2016. "Growth, Poverty Reduction and Inequality. In Growth and Poverty in Sub-Saharan Africa, edited by C. Arndt, A. McKay, and F. Tarp, Chapter 6. doi:10. 1093/acprof:oso/9780198744795.001.0001.

McMillan, M., and D. Heady. 2014. "Introduction - Understanding Structural Transformation in Africa." World Development 63 (November): 1-10.

MINAGRI (Ministry of Agriculture and Animal Resources). 2011. Strategies for Sustainable Crop Intensification in Rwanda: Shifting Focus from Producing Enough to Producing Surplus. Kigali: MINAGRI.

MINALOC (Ministry of Local Government)/MINAGRI. 2016. Twigire Muhinzi: Homegrown solution to increase farm yields and foster solidarity. Kigali: Republic of Rwanda.

MINECOFIN (Ministry of Finance and Economic Planning). 2000. Rwanda Vision 2020. Kigali: Republic of Rwanda.

Musahara, H., and C. Huggins. 2005. "Land Reform, Land Scarcity and PostcConflict Reconstruction: A Case Study of Rwanda." In From the Ground Up: Land Rights, Conflict and Peace in sub-Saharan Africa, edited by C. Huggins and J. Clover, 269-346. Pretoria: Institute for Security Studies. 
NISR (National Institute of Statistics of Rwanda). 2010. National Agricultural Survey 2008. Kigali: NISR.

NISR. 2012. The Evolution of Poverty in Rwanda from 2000 to 2011: Results from the Household Surveys. Kigali: NISR.

NISR. 2015a. Results of Integrated Household Living Conditions Survey 2013/14. Kigali: NISR.

NISR. 2015b. Visa Instruction Manual (version 2). Kigali: Republic of Rwanda.

NISR. 2016. Poverty Trend Analysis Report 2010/11-2013/14. Kigali: NISR.

Ntirenganya, E. 2016. “Farmers Welcome New Seeds, Fertilisers' Distribution Model." The New Times, September 26. http://www.newtimes.co.rw/section/article/2016-09-26/203872/.

Nyenyezi Bisoka, A. 2014. "L'agriculture paysanne en Afrique des Grand Lacs: vers un démantèlement? Rationalités et enjeux." In Agro-écologie. Enjeux et perspectives, edited by L. Delcourt, 193-208. Louvain-la-Neuve: Centre Tricontinental (CETRI), AS-Agroécologie.

Nyenyezi Bisoka, A. 2016. "Invention de la terre et production des anormaux dans le dispositif foncier en Afrique. Pouvoir et résistance à l'accaparement des terres en Afrique des Grands Lacs." PhD diss., Université catholique de Louvain, Collection de thèses de l'Université catholique de Louvain.

Oliver de Sardan, J.-P. 2008. La rigueur du qualitatif. Les contraintes empiriques de l'interprétation socio-anthropologique. Louvain-la-Neuve: Academia-Bruylant.

Panait, O. M., and A. Nyenyezi Bisoka. 2014. "L'Agaciro rwandais: discours postdéveloppementaliste ou usurpation de la lutte postcoloniale? - légitimation et dé-légitimation d'un discours." In L'Afrique des Grands Lacs: Annuaire 2013-2014, edited by S. Marysse, F. Reyntjens, and S. Vandeginste, 361-384. Paris: L'Harmattan.

Purdeková, A. 2011. “'Even if I Am Not Here, There Are So Many Eyes': Surveillance and State Reach in Rwanda.” The Journal of Modern African Studies 49: 475-497.

Republic of Rwanda. 2004. National Land Policy. Kigali: Republic of Rwanda.

Republic of Rwanda. 2007. Phase 1 of the Land Reform Process for Rwanda: Results of Preparatory Field Consultations in Four Trial Districts; March-October 2006. Kigali: DFID/HTSPE/ MINITERE.

RGB (Rwanda Governance Board). 2014. Rwanda Citizen Report Card 2013. Kigali: RGB.

RGB. 2017. Citizen Report Card 2016. Kigali: RGB.

RISD (Rwanda Initiative for Sustainable Development). 2012. The Impact of land Lease Fee on Landowners: Rwanda Case Study. Kigali: RISD.

RISD. 2013. Securing Land Rights Project: A Working Paper on Land Tenure Regularization in Rwanda. Kigali: RISD.

Rwanda Cooperative Agency. 2015. "Ubuhinzi Cooperatives Registered so Far.” Kigali: Rwanda Cooperative Agency. Accessed February 16, 2017. www.rca.gov.rw/IMG/pdf/ubuhinziok.pdf.

Sanchez, P. A., G. L. Denning, and G. Nziguheba. 2009. "The African Green Revolution Moves Forward." Food Security 1 (1): 37-44.

Sandefur, J., and A. Glassman. 2015. "The Political Economy of Bad Data: Evidence from African Survey and Administrative Statistics." The Journal of Development Studies 51 (2): 116-132.

Scott, J. 1998. Seeing Like a State: How Certain Schemes to Improve the Human Condition Have Failed. New Haven and London: Yale University Press.

Sommers, M. 2012. Stuck: Rwandan Youth and the Struggle for Adulthood. Athens, GA: University of Georgia Press.

Treidl, J. 2018. "Sowing Gender Policies, Cultivating Agrarian Change, Reaping Inequality? Intersections of Gender and Class in the Context of Marshland Transformations in Rwanda." Antropologia, forthcoming.

UNDP (United Nations Development Programme). 2007. Turning Vision 2020 into Reality: From Recovery to Sustainable Human Development: National Human Development Report. United Nations Development Programme, Rwanda 2007. New York: UNDP.

University of Rwanda. 2014. Assessment of the Economic, Social, and Environmental Impacts of the Land Use Consolidation Component of the Crop Intensification Program in Rwanda. Kigali: USAID Rwanda LAND Project. 
Van Damme, J. 2013. "Analyse systémique des processus d'innovation dans les systèmes agraires de la region des Grands Lacs basés sur la culture de la banane.” PhD diss., Université catholique de Louvain.

Van Damme, J., A. Ansoms, and P. Baret. 2013. “Agricultural Innovation from Above and from Below: Confrontation and Integration on Rwanda's Rural Hills.” African Affairs 113 (450): 128-137.

Van Hoyweghen, S. 1999. “The Urgency of Land and Agrarian Reform in Rwanda." African Affairs 98 (392): 353-372.

Verhofstadt, E., and M. Maertens. 2014. "Can Agricultural Cooperatives Reduce Poverty? Heterogeneous Impact of Cooperative Membership on Farmers' Welfare in Rwanda.” Applied Economic Perspectives and Policy 37: 86-106.

Wanjala, B. M., and R. Muradian. 2013. "Can Big Push Interventions take Small-scale Farmers out of Poverty? Insights from the Sauri Millennium Village in Kenya.” World Development 45 (C): 147-160.

Watkiss, P. 2015. Mainstreaming Climate Information into Sector Development Plans: The Case of Rwanda's Tea and Coffee Sectors (Second edition, December 2015). London/Cape Town: Future Climate for Africa. 